\title{
Implementation and Impact of Human Resources Development in Improving the Performance of Teachers in Schools (Multi Case Studies)
}

Muh Burhanudin Harahap ${ }^{1}$ Maria Veronika Roesminingsih ${ }^{2}$, Mudjito $^{3}$

1,2,3 Doctoral Program of Education Management, Universitas Negeri Surabaya, Surabaya, Indonesia

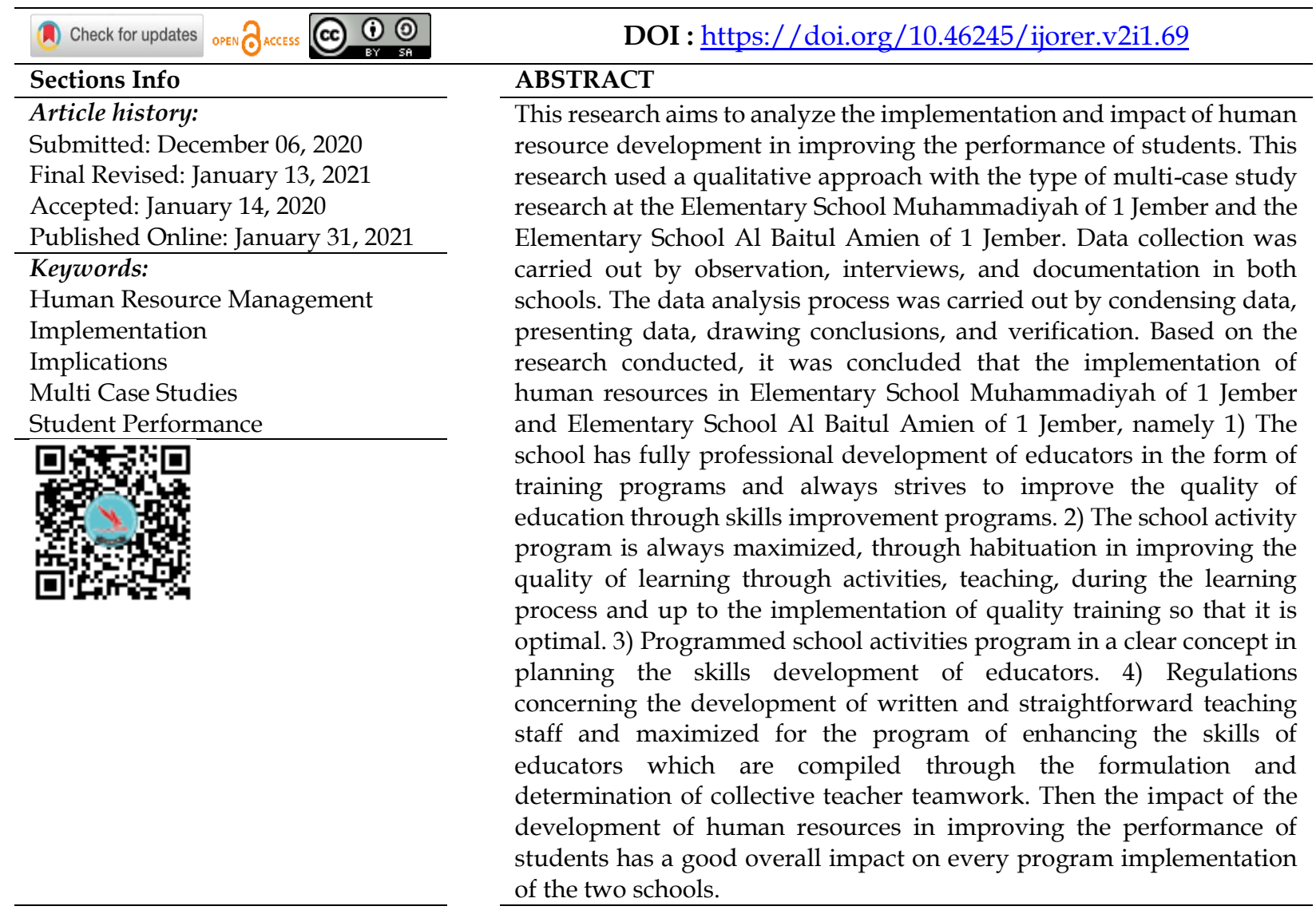

\section{INTRODUCTION}

Education has a comprehensive and universal nature, this trait can be integrated through attitudes and educational spaces (David, 2014). Education will gradually continue to teach knowledge, attitudes, and skills to provide prosperity and world development. In this case, teaching that can develop students' skills and knowledge appropriately is needed (Tam et al., 2018; Ferristone et al., 2020). Developed countries have a high level of awareness in implementing productive human resources (Nadarajah, 2012). So that education must continue to develop following the development of information technology which has significantly increased. Both academically and non-academically (Bair \& Bair, 2011; Austin \& Sorcinelli, 2013). So that in this case human resources along with all supporting infrastructure managers must always be progressed well (Nadarajah, 2012).

Excellent human resources are needed in the world of education (Saw \& Watana, 2020). Human resources who have self-integrity and good performance will influence the 
Implementation and Impact of Human Resources Development in Improving the Performance of Teachers in Schools (Multi Case Studies)

processes of implementing educational programs (Vosloban, 2012), both in educational institutions and in an organization. Human resources who keep abreast of the times will have extensive experience and insight. To be able to participate in developing skills and knowledge in this matter, good communication and collaboration between colleagues and employees are needed (Amundsen \& Wilson, 2012). All members of the agency need to continue to collaborate in improving performance. Superior schools will be able to improve self-integrity through cooperation among colleagues and together in improving performance, not only education authorities who play a role.

In creating an effective and superior school, apart from producing students who can be highly competitive, it is very necessary to design and plan a curriculum very well. This is the role of teachers, educators, and all levels of their colleagues that must be committed and capable of high quality (Wijaya et al; Mangkunegara, 2011; Tenggala, 2013; Jennifer et al., 2017). All school resources must be able to be optimally utilized to achieve a superior and quality school (Talan \& Tyagi, 2020; Bearman et al, 2012; Zuhro, 2015). So that both school principals, deputy principals, curriculum personnel, teachers, students, staff, and all office holders in an agency must play an active role and collaborate well (Irmayani et al., 2018), this is because it will create an atmosphere that is spirit (Omebe, 2014; Septi, 2017).

Decentralization and educational arrangements will run well if the principal or school leader can empower all members maximally, and are monitored continuously (Omebe, 2014; Kumaedi et al., 2010). Principals are strongly advised to be able to improve their abilities functionally, so that students and teachers and other ranks can play a role by their respective main tasks and functions (Wijaya \& Nyoto, 2016; Krismiyati, 2017; Suharto, 2017). To resolve these problems, this study was conducted to determine how the implementation and impact of human resource development in improving performance at Elementary School Muhammadiyah of 1 Jember and in Elementary School Al Baitul Amien of 1 Jember, to improve performance optimally in both schools.

\section{RESEARCH METHOD \\ General Background}

This research uses qualitative research with the type of evaluation research. In the process of conducting research, there is a process of formative evaluation and summative evaluation. The research design used a multi-case study by describing the data obtained. The multi-case study used was comparing two different research sites. This research was conducted in depth (Jaeni et al., 2020 \& Widodo et al., 2020).

\section{Sample/Participant}

The research sample used is the management of the foundation, namely the Elementary School Muhammadiyah of 1 Jember and the Elementary School Al Baitul Amien of 1 Jember. The research sample consisted of principals, deputy principals, curriculum staff, teachers and educators, school staff and all levels of the management of the two schools' foundations.

\section{Instruments and Procedures}

In obtaining data the researcher came to the research subject to conduct an interview. The interview process was carried out in stages. Collecting research data using participatory 
Implementation and Impact of Human Resources Development in Improving the Performance of Teachers in Schools (Multi Case Studies)

observation techniques, structured and in-depth interviews, and documentation of some of the existing data at school. Research with a qualitative approach was conducted with 4 criteria for data validity, namely credibility, transfability, dependability, and confirmability. The research instrument used for the interview has been said to be valid, so that it can be used further to obtain research data.

\section{Data Analysis}

The data analysis process was carried out in 3 steps. The first is data condensation, namely the process of selecting, simplifying, and transforming data that is close to the overall data, whether through interviews, documentation, or observations. Second, the presentation of data, namely the process of concluding some of the information obtained. Third, namely drawing conclusions and verification.

\section{RESULTS AND DISCUSSION}

Implementation of Human Resource Development (PSDM) carried out by schools in improving the performance of teaching staff at Elementary School Muhammadiyah of 1 Jember

\section{Single case study findings:}

The research findings on the first site are related to the implementation of Human Resource development carried out by schools in improving the performance of teaching staff at Elementary School Muhammadiyah of 1 Jember. Based on the exposure to research data, the researcher found the findings of research notes related to the implementation of human resource development at Elementary School Muhammadiyah of 1 Jember, which are presented in Table 1.

Table 1. Implementation of human resource development carried out by schools in improving the performance of teaching staff at Elementary School Muhammadiyah of 1 Jember.

\begin{tabular}{clll}
\hline Numb. & \multicolumn{1}{c}{ Findings } & \multicolumn{1}{c}{ Finding Notes } \\
\hline 1 & $\begin{array}{l}\text { The development of educator } \\
\text { skills is supported by } \\
\text { increased performance }\end{array}$ & 1) & $\begin{array}{l}\text { Supported by the provision of facilities in } \\
\text { learning }\end{array}$ \\
\hline 2 & 2) $\begin{array}{l}\text { Improved performance improvement } \\
\text { pevelopment is in line with } \\
\text { the analysis of the needs for } \\
\text { the implementation of } \\
\text { transfers and promotions }\end{array}$ & 1) & $\begin{array}{l}\text { Program implementation is carried out } \\
\text { periodically, clearly and in writing }\end{array}$ \\
& 2) & $\begin{array}{l}\text { Increase the potential and program } \\
\text { development supported by needs analysis }\end{array}$ \\
\hline 3 & 3) $\begin{array}{l}\text { Improvements in educator skills are } \\
\text { developed }\end{array}$ \\
$\begin{array}{l}\text { Performance and competency } \\
\text { accompanied by changes in } \\
\text { attitude and discipline }\end{array}$ & 1) & $\begin{array}{l}\text { Changes in attitude and good behavior } \\
\text { improve learning performance and quality } \\
\text { The implementation of the task of pursuing } \\
\text { professionalism }\end{array}$ \\
\hline
\end{tabular}

Based on the record of findings obtained by researchers, in developing human resources for educators and educational personnel at the Muhammadiyah 1 Jember Elementary School, it was carried out by two methods, namely on the job training and off 
Implementation and Impact of Human Resources Development in Improving the Performance of Teachers in Schools (Multi Case Studies)

the job training. Educator human resource development included in on the job training includes job rotation, training, guidance/counseling, job instructor training, demonstrations / giving examples, and temporary assignments, while those included in the off the job training method include: courses, education, workshops, seminars, and subject teacher deliberations. On the job training conducted by the Elementary School Muhammadiyah of 1 Jember includes 1) Position Rotation, Job rotation can also be used as a new experience given to educators to improve professionalism. This is as expressed by the principal:

"To develop human resources for teaching staff, the school provides the opportunity for each educator to occupy a certain position by rotating positions so that each educator feels certain positions within 1 year. For example, in the division of tasks in the 2018/2019 academic year being class III guardian, then in the 2019/2020 school year is the guardian of class IV and so on or the 2018/2019 academic year being the commemoration committee for the Islamic Holidays for the 2019/2020 school year to become the Student Registration committee. New, or for example, in the 2018/2019 academic year, there will be additional student assignments, so in the 2019/2020 school year, it will become the curriculum, and so on. " W.4-1/BMS/HEAD/MUH1JBR /8/2019

Then carried out 2) Training (Training). Every year the Elementary School Muhammadiyah of 1 Jember organizes training for educators and education personnel at least 2 times because this training is tailored to the needs. 3) Guidance / Counseling, this can be done in a way that educators must carry out their duties with the guidance of senior officials/experts or more senior colleagues. The guidance carried out at the Elementary School Muhammadiyah of 1 Jember is general and conditional because the implementation is not scheduled, sometimes it is held at the beginning of the school year even after the teaching and learning activities are finished. 4) Job Instructor Training, To increase the professionalism of educators at the Elementary School Muhammadiyah of 1 Jember to hold several instructor exercises including filling in the processing of grades in the daily assessment, mid-semester assessment, final semester assessment to processing report cards based on the 2013 curriculum, several staff are required. educators to attend job instructor training then some of these people become instructors for other educators as a whole. 5) Demonstrations and examples.

In improving the competence of educators (teachers) at Elementary School Muhammadiyah of 1 Jember, to implement the 2013 curriculum, schools held demonstrations and gave examples of how to do learning using LCD learning media, using the internet, using youtube so that the learning process was not boring, and this could develop the skills of teachers (teachers) in teaching (Hidayatullah et al., 2020), in the process of learning the skills of an educator with facilities will not be separated. The use of school facilities in the learning process will make it easier for students to gain knowledge and insight, and help teacher efficiency (Lince, 2016; Irmayani et al., 2018). 6) Temporary Assignment. Meanwhile, what is included in the Off The Job Training method carried out by this school include: courses, education, workshops, seminars, and Subject Teacher Deliberation. Through some implementation of activities in improving the performance of students, it needs to be done continuously or continuously. To obtain perfection in the human resource management system in schools requires continuous 
Implementation and Impact of Human Resources Development in Improving the Performance of Teachers in Schools (Multi Case Studies)

stages which are steps in improving the performance of students (Irmayani et al., 2018; Nadarajah, 2012; Wiajaya et al, 2016; Tenggala, 2013).

Implementation of Human Resources (HR) development carried out by schools in improving the performance of teaching staff at Elementary School Al Baitul Amien of 1 Jember

Single case study findings:

The research findings on the second site are related to the implementation of Human Resource development carried out by schools in improving the performance of teaching staff at Elementary School Al Baitul Amien of 1 Jember. Based on the explanation of research data that has been previously stated, the researcher found the findings of research notes related to the implementation of human resource development in Elementary School Al Baitul Amien of 1 Jember, which are presented in Table 2.

Table 2. Implementation of human resource development carried out by schools in improving the performance of teaching staff at Elementary School Al Baitul Amien of 1 Jember.

\begin{tabular}{|c|c|c|}
\hline Numb. & $\begin{array}{l}\text { Findings } \\
\end{array}$ & Finding Notes \\
\hline 1 & $\begin{array}{l}\text { The development of educator skills } \\
\text { is supported by increased } \\
\text { performance }\end{array}$ & $\begin{array}{l}\text { 1) Supported by the provision of facilities in } \\
\text { learning } \\
\text { 2) Increasing the performance improvement } \\
\text { program }\end{array}$ \\
\hline 2 & $\begin{array}{l}\text { Development is in line with the } \\
\text { analysis of the needs for the } \\
\text { implementation of transfers and } \\
\text { promotions }\end{array}$ & $\begin{array}{l}\text { 1) Program implementation is carried out } \\
\text { periodically } \\
\text { 2) Increase the potential and program } \\
\text { development supported by needs analysis } \\
\text { 3) Improvements in educator skills are } \\
\text { developed }\end{array}$ \\
\hline 3 & $\begin{array}{l}\text { Performance and competency } \\
\text { improvements are accompanied by } \\
\text { changes in attitude and discipline }\end{array}$ & $\begin{array}{l}\text { 1) Changes in attitude and good behavior } \\
\text { improve learning performance and quality } \\
\text { 2) The implementation of teaching duties } \\
\text { becomes professional }\end{array}$ \\
\hline
\end{tabular}

Based on the research data, it was revealed that the training program was carried out by planning, this is also similar to what was stated by the Principal of Elementary School Al Baitul Amien of 1 Jember in an interview with researchers as follows:

"We have planned the training planning since the beginning of the school year and at the time of compiling the work program, and we have explained it at the work meeting. We also ask for input from all parties related to how the training is appropriate and according to the needs of all educators and education personnel ". W.2/BMS/HEAD/ALAMIN1JBR/8/2019

In implementing the program to obtain good results, an assessment of a program is needed to determine the results of the program that was carried out successfully or not. For this reason, the Elementary School Al Baitul Amien of 1 Jember, when conducting programs related to development, especially the development of human educators, is at 
Implementation and Impact of Human Resources Development in Improving the Performance of Teachers in Schools (Multi Case Studies)

the end of the implementation of the development program, an assessment is held to find out the results obtained from the program.

Curriculum development workshops are usually held once every semester, at the beginning of the semester during school holidays. Thus, development workshops are usually conducted 2 times a year. The refined 2013 curriculum implementation workshop includes the policies of the Ministry of Education and Culture of the Republic of Indonesia regarding the implementation of the 2013 curriculum in schools, the mindset of teachers in facing the 2013 curriculum, 2013 curriculum rationalization, scientific learning, authentic assessment, graduate competency analysis, core competencies, basic competencies, preparation of implementation plans learning and learning outcomes reports in the 2013 curriculum This is confirmed by the existence of workshops carried out and led by the principal, the Principal of Al Baitul Amien 1 Jember Elementary School who stated:

"The workshop activities take students' vacation time and are held for 3-4 days. This is as expressed by the Deputy Head of the Elementary School Curriculum section of Al Baitul Amien 1 Jember

W.2/BMS/HEAD/ALAMIN1JBR/8/2019.

The syllabus development workshop program and learning tools have been running for a long time from year to year. The hope is that before the new semester or new school year starts, all of the curriculum tools will be completed. Thus, later educators will stay focused on learning. Because the learning equipment has been prepared during the holidays. For the development workshop activities tailored to the needs, an average of 34 days. Meanwhile, the other material for one semester was completed by each educator with a workshop result model. Based on the explanation above, it can be concluded that the Elementary School Al Baitul Amien of 1 Jember in developing human resources for educators is carried out in several steps, including programming, determining needs, determining targets, determining programs, identifying learning principles, implementing programs and evaluating program implementation. These steps will improve the performance and skills of human resources in schools (Mukolwe et al., 2017). Implementation of human resource development for educators at the Elementary School Al Baitul Amien of 1 Jember is carried out in formal and informal ways. Formally development is carried out using educators assigned to attend education and training both carried out by organizations and those carried out by educational institutions. Informal development is carried out based on desire and one's efforts.

Cross-Site Findings regarding the implementation of Human Resource Development by schools in improving the performance of teaching staff at the Elementary School Muhammadiyah of 1 Jember and the Elementary School Al Baitul Amien of 1 Jember. Referring to the results of individual case studies for each institution in the two schools, namely the Elementary School Muhammadiyah of 1 Jember and the Elementary School Al Baitul Amien of 1 Jember, a comparison is found in Figure 1. 


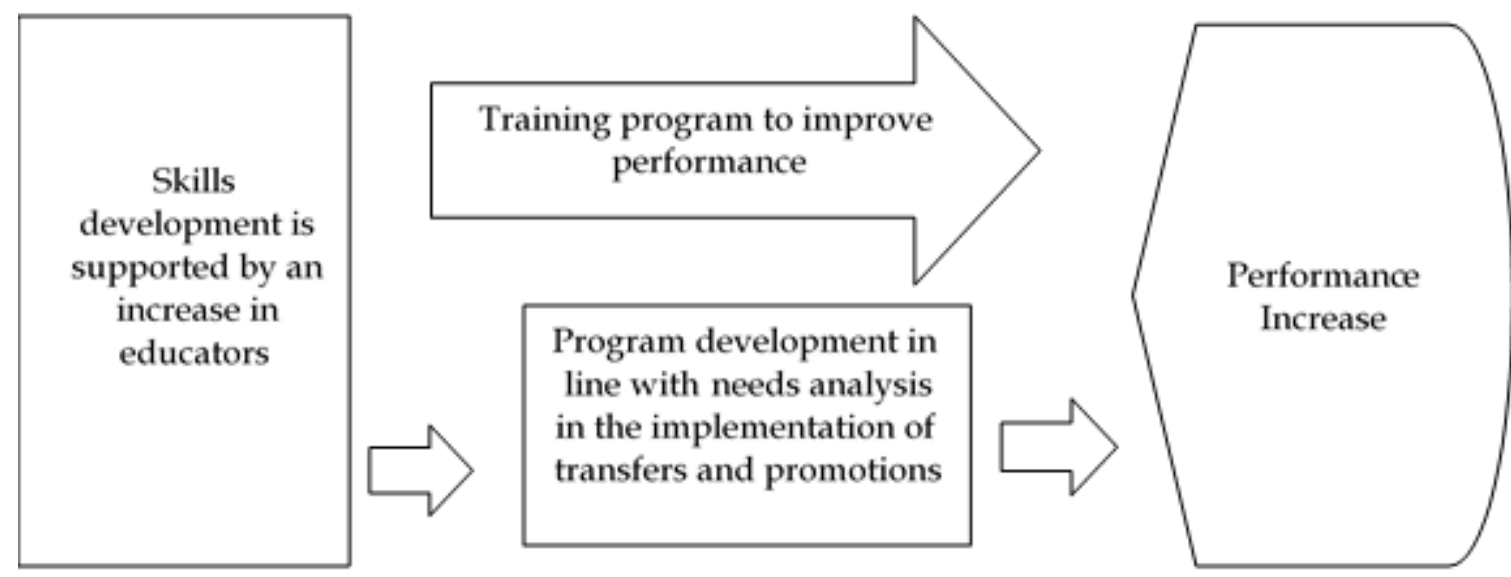

Figure 1. Improved performance through human resource management.

Based on the Figure 1, several explanations can be described, namely: Development of teacher improvement is carried out through skills training programs as an effort to improve learning through performance. The maximum training is carried out together with a collaborative system with methods that vary with learning, to produce maximum learning. Referring to the results of individual case studies for each of these institutions, namely Elementary School Muhammadiyah of 1 Jember and the Elementary School Al Baitul Amien of 1 Jember, a cross-case analysis was found based on the comparative findings as presented in Table 3 .

Table 3. Cross-Site Analysis About the implementation of Human Resources development carried out by schools in improving the performance of teaching staff at Elementary School Muhammadiyah of 1 Jember and the Elementary School Al Baitul Amien of 1 Jember.

\begin{tabular}{|c|c|c|c|}
\hline Numb. & Item & $\begin{array}{c}\text { Elementary School } \\
\text { Muhammadiyah of } 1 \text { Jember }\end{array}$ & $\begin{array}{c}\text { Elementary School Al Baitul } \\
\text { Amien of } 1 \text { Jember }\end{array}$ \\
\hline 1 & $\begin{array}{l}\text { The } \\
\text { development of } \\
\text { educator skills is } \\
\text { supported by } \\
\text { increased } \\
\text { performance }\end{array}$ & $\begin{array}{l}\text { 1) Supported by the provision } \\
\text { of facilities in learning } \\
\text { 2) Increasing the performance } \\
\text { improvement program }\end{array}$ & $\begin{array}{l}\text { 1) Supported by the provision } \\
\text { of facilities in learning } \\
\text { 2) Increasing the performance } \\
\text { improvement program }\end{array}$ \\
\hline 2 & $\begin{array}{l}\text { Development is } \\
\text { in line with the } \\
\text { analysis of the } \\
\text { needs for the } \\
\text { implementation } \\
\text { of transfers and } \\
\text { promotions }\end{array}$ & $\begin{array}{l}\text { 1) Program implementation is } \\
\text { carried out regularly, } \\
\text { clearly and in writing } \\
\text { 2) Increase the potential and } \\
\text { program development } \\
\text { supported by needs } \\
\text { analysis } \\
\text { 3) Improved skills of } \\
\text { educators are developed }\end{array}$ & $\begin{array}{l}\text { 1) Program implementation is } \\
\text { carried out regularly } \\
\text { 2) Increase the potential and } \\
\text { program development } \\
\text { supported by needs } \\
\text { analysis } \\
\text { 3) Improved skills of } \\
\text { educators are developed }\end{array}$ \\
\hline
\end{tabular}


Implementation and Impact of Human Resources Development in Improving the Performance of Teachers in Schools (Multi Case Studies)

\begin{tabular}{|c|c|c|c|}
\hline Numb. & Item & $\begin{array}{c}\text { Elementary School } \\
\text { Muhammadiyah of } 1 \text { Jember }\end{array}$ & $\begin{array}{c}\text { Elementary School Al Baitul } \\
\text { Amien of } 1 \text { Jember }\end{array}$ \\
\hline 3 & $\begin{array}{l}\text { Performance and } \\
\text { competency } \\
\text { improvements } \\
\text { are accompanied } \\
\text { by changes in } \\
\text { attitude and } \\
\text { discipline }\end{array}$ & $\begin{array}{l}\text { 1) Changes in attitude and } \\
\text { good behavior increase the } \\
\text { performance and quality of } \\
\text { learning } \\
\text { 2) Implementation of } \\
\text { pursuing tasks to become } \\
\text { professional }\end{array}$ & $\begin{array}{l}\text { 1) Changes in attitude and } \\
\text { good behavior increase the } \\
\text { performance and quality of } \\
\text { learning } \\
\text { 2) Implementation of } \\
\text { pursuing tasks to become } \\
\text { professional }\end{array}$ \\
\hline
\end{tabular}

Based on the comparison of the implementation of Human Resource Development carried out by schools in improving the performance of teaching staff at the Elementary School Muhammadiyah of 1 Jember and the Elementary School Al Baitul Amien of 1 Jember, it can be concluded that the intersection of the results of the cross-site analysis is as follows; 1) The school has fully professional development of educators in the form of training programs and always strives to improve the quality of education through skills improvement programs. through improving the performance of the teaching staff, 2) The school activity program is always being maximally enhanced, through habituation in improving the quality of learning through activities, teaching, during the learning process and up to the implementation of quality training so that it is optimal. 3) Programmed school activities program in a clear concept in planning the skills development of educators. The implications in program design involve many components in learning, design ranging from material to evaluation, and improvement in communicating and interacting as a group which is always maximized (Suhardan, 2014; Suharto, 2017). 4) Regulations concerning the development of written and straightforward teaching staff and maximized for the program of enhancing the skills of educators which are compiled through the formulation and determination of collective teacher teamwork.

Cross-Site Findings regarding the implications (impacts) of Human Resource Development carried out by schools in improving performance at Elementary School Muhammadiyah of 1 Jember and the Elementary School Al Baitul Amien of 1 Jember. Referring to the results of individual case studies for each institution at the two schools, namely the Elementary School Muhammadiyah of 1 Jember and the Elementary School Al Baitul Amien of 1 Jember, a comparison is found in Figure 2.

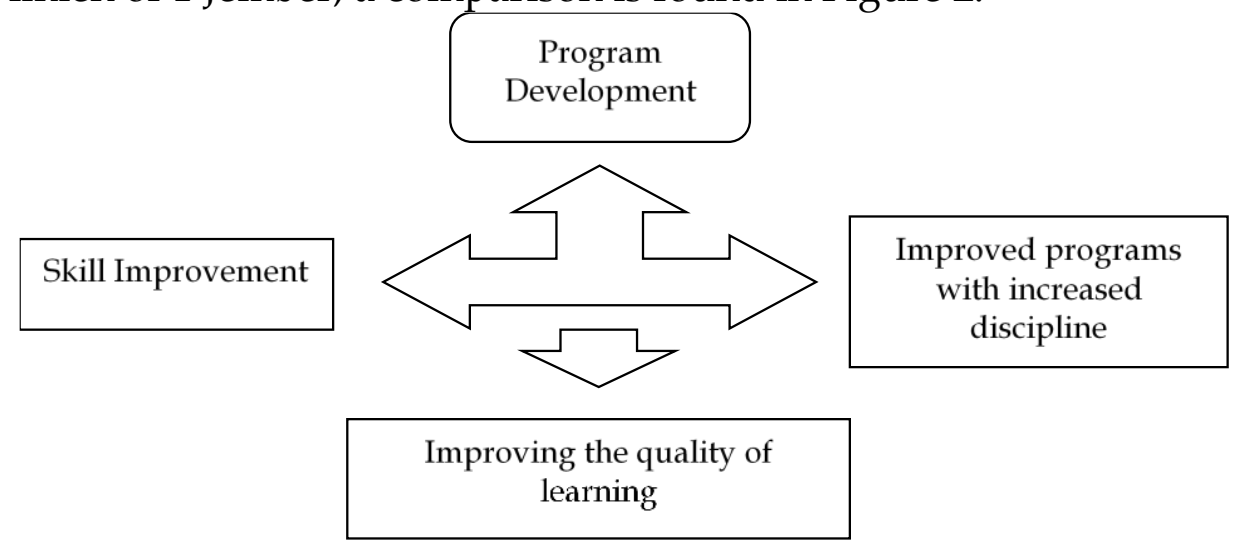

Figure 2. Improving the training program to improve the quality of learning. 
Implementation and Impact of Human Resources Development in Improving the Performance of Teachers in Schools (Multi Case Studies)

From the picture above, several explanations can be explained, namely: The school has several supporting documents for the development of educator skills training programs so that all teachers understand and can apply to learn correctly and all teachers can maximize the quality of learning through training programs in recruitment and transfer and develop teaching materials based on the syllabus and Learning Implementation Plans used in learning to improve the quality of learning.

Cross-Site Analysis of the Implication (impact) of Human Resource Development carried out by schools in improving performance at Elementary School Muhammadiyah of 1 Jember and the Elementary School Al Baitul Amien of 1 Jember.

Table 4. Cross-site analysis of implications (impacts) of Human Resource Development carried out by schools in improving performance in Elementary School Muhammadiyah of 1 Jember and the Elementary School Al Baitul Amien of 1 Jember.

\begin{tabular}{|c|c|c|c|}
\hline Numb. & Item & $\begin{array}{c}\text { Elementary School } \\
\text { Muhammadiyah of } 1 \text { Jember }\end{array}$ & $\begin{array}{c}\text { Elementary School Al Baitul } \\
\text { Amien of } 1 \text { Jember }\end{array}$ \\
\hline 1 & $\begin{array}{l}\text { The } \\
\text { development } \\
\text { of educator } \\
\text { skills is clearly } \\
\text { conceptualized } \\
\text { in school } \\
\text { programs }\end{array}$ & $\begin{array}{l}\text { 1) Supported by the } \\
\text { provision of training } \\
\text { programs in learning } \\
\text { 2) Increasing the training } \\
\text { program program }\end{array}$ & $\begin{array}{l}\text { 1) Supported by the provision } \\
\text { of facilities in learning } \\
\text { 2) The improvement of the } \\
\text { expertise program program } \\
\text { has been planned at the } \\
\text { beginning of every } \\
\text { planning }\end{array}$ \\
\hline 2 & $\begin{array}{l}\text { Development } \\
\text { goes hand in } \\
\text { hand with } \\
\text { planning in a } \\
\text { training } \\
\text { program }\end{array}$ & $\begin{array}{l}\text { 1) Program implementation } \\
\text { is carried out regularly } \\
\text { with a clear concept } \\
\text { 2) Increase the potential and } \\
\text { program development in a } \\
\text { mature manner } \\
\text { 3) Increasing the skills of } \\
\text { educators is developed in } \\
\text { a planned manner }\end{array}$ & $\begin{array}{l}\text { 1) Program implementation is } \\
\text { carried out periodically } \\
\text { 2) Increase the potential and } \\
\text { development of programs } \\
\text { supported by increased } \\
\text { resources } \\
\text { 3) Improvement of educator } \\
\text { skills is developed through } \\
\text { training }\end{array}$ \\
\hline 3 & $\begin{array}{l}\text { Improved } \\
\text { training } \\
\text { programs to } \\
\text { improve } \\
\text { attitude and } \\
\text { discipline } \\
\text { changes }\end{array}$ & $\begin{array}{l}\text { 1) The implementation of a } \\
\text { good program is in line } \\
\text { with the improvement of } \\
\text { attitudes and behavior in } \\
\text { improving the quality of } \\
\text { learning } \\
\text { 2) Implementing professional } \\
\text { training programs }\end{array}$ & $\begin{array}{l}\text { 1) The implementation of the } \\
\text { program has gone well and } \\
\text { is planned in line with the } \\
\text { quality improvement } \\
\text { 2) Increasing effective and } \\
\text { efficient targeted and clear } \\
\text { training programs }\end{array}$ \\
\hline
\end{tabular}

Based on the comparison of the implications (impact) of Human Resource Development carried out by schools in improving performance at the Elementary School Muhammadiyah of 1 Jember and the Elementary School Al Baitul Amien of 1 Jember, a meeting point can be taken from the results of the cross-site analysis, namely a) The school develops training programs optimally and always strive to improve the quality of education through skills improvement programs through improving the performance of 
Implementation and Impact of Human Resources Development in Improving the Performance of Teachers in Schools (Multi Case Studies)

educators (Fahrudin, 2015; Maamarah \& Supramono, 2016) b) School activity programs are always being improved with the maximum level of effectiveness and efficiency, habituation in improving the quality of learning through activities, teaching, during the learning process and up to the implementation of quality training so that it is optimal, c) Programmed school activity programs in a clear concept in planning the skills development of educators. Program design involves many components in learning, design ranging from material to evaluation, and improvement of training program programs carried out in groups, d) Regulations on written and straightforward teacher development and maximized for educator skills enhancement programs compiled through the formulation and assignment of the work team of teachers together. Some of the challenges in the program of these activities will be able to optimize the achievement of education quality ((Fahrudin 2015; Maamarah \& Supramono, 2016; Suharto, 2017; Suhardan, 2014).

\section{CONCLUSIONS}

Based on the research conducted, it can be concluded that the implementation of human resources in Elementary School Muhammadiyah of 1 Jember and the Elementary School Al Baitul Amien of 1 Jember, namely 1) The school has fully professional development of educators in the form of training programs and always strives to improve the quality of education through skills improvement programs. 2) The school activity program is always maximized, through habituation in improving the quality of learning through activities, teaching, during the learning process, and up to the implementation of quality training so that it is optimal. 3) Programmed school activities program in a clear concept in planning the skills development of educators. The implications in program design involve many components in learning, design ranging from material to evaluation, and improvement in communicating and interacting as a group which is always maximized. 4) Regulations concerning the development of written and straightforward teaching staff and maximized for the program of enhancing the skills of educators which are compiled through the formulation and determination of collective teacher teamwork. Then the impact of the development of human resources in improving the performance of students has a good overall impact on every program implementation of the two schools. The limit of research is carried out at the level of elementary school education, it is very necessary to be further tested at higher schools that have different conditions and environments. So that future research can be used and tested with broader data and at a higher school level.

\section{ACKNOWLEDGEMENTS}

The research team thanks all leaders at the Faculty of Education Management, State University of Surabaya, all teachers of the Elementary School Muhammadiyah of 1 Jember and the Elementary School Al Baitul Amien of 1 Jember who have helped and provided support for this research.

\section{REFERENCES}

Amundsen, C., \& Wilson, M. (2012). Are we asking the right questions?: A conceptual review of the educational development literature in higher education. Review of Educational Research, 82(1), 90-126. 
Implementation and Impact of Human Resources Development in Improving the Performance of Teachers in Schools (Multi Case Studies)

Austin, A. E., \& Sorcinelli, M. D. (2013). The future of faculty development: Where are we going?. New Directions for Teaching and Learning, 133, 85-97.

Bair, D. E., \& Bair, M. A. (2011). Paradoxes of online teaching. International Journal for the Scholarship of Teaching E Learning, 5(2), 1-15.

Bearman, M., Smith, C.D., Carbone, A., Slade, S., Baik, C., Hughes-Warrington, M.,

\& Neumann, D. L. (2012). Systematic review methodology in higher education. Higher Education Research \& Development, 31(5), 625-640.

David, N. (2018). Gratitude as an enactment of democratic citizenship education. South African Journal of Higher Education, 28(5), 1513-1524.

Fahrudin, (2015). Peningkatan kinerja dan pengembangan profesionalitas guru sebagai upaya peningkatan mutu pendidikan di indonesia. Prosiding Seminar Nasional Pendidikan Ekonomi \& Bisnis.

Firestone, A. R., Rebecca, A., Cruz., \& Janelle, E. (2020). Teacher Study Groups: An Integrative Literature Synthesis. Review of Educational Research, 90(5), 675709.

Hidayatullah, R. S., Ariyanto, S. R., Muhaji, Mubarok, H., \& Yohannes, A. (2020). Collaborative Problem-based Learning: An Analysis of Problem-Solving Skills in Vocational Schools. International Journal of Recent Educational Research, 1(3), 209-217. Irmayani, H., Wardiah, D., \& Kristiawan, M. (2018). The strategy of sd pusri in improving educational quality. International Journal of Scientific $\mathcal{E}$ Technology Research, 7(7). 113-121.

Jaeni, U., Basuki, I., \& Moedjiarto. (2020). Culture learning management al-quran model tilawati to improve student character. International Journal of Recent Educational Research, 1(3), 286-300.

Jennifer, G., Adam. L., Maxwell, S., Julie, B., Hywel, E., \& David, L. (2017). Effects of professional development on the quality of teaching: Results from randomised controlled trial of Quality Teaching Rounds. Teaching and Teacher Education, 68, 99-113.

Tenggala, (2013). Analisis implementasi kebijakan pengelolaan sarana dan prasarana sekolah di SMP Negeri 2 Batu Martinus Tanggela. Jurnal Kebijakan dan Pengembangan Pendidikan, 1(1), 26-34.

Khummaedi., Muhammad., Sunyoto., \& Wijaya, M.B.R. (2010). Kesesuaian program keahlian di sekolah menengah kejuruan dengan kebutuhan tenaga kerja di kabupaten semarang. Jurnal Pendidikan Teknik Mesin, 10(1), 29-35.

Krismiyati. (2017). Pengembangan sumber daya manusia dalam meningkatkan kualitas pendidikan di SD negeri inpres angkasa biak. Jurnal Office, 3(1), 43-50.

Lince, R. (2016). Strategi peningkatan profesionalisme guru dalam menghadapi tantangan di era digital. Prosiding Temu Ilmiah Nasional Guru

Maamarah., Siti., \& Supramono. (2016). Strategi peningkatan mutu dan citra sekolah dasar negeri di ungaran semarang. Jurnal Manajemen Pendidikan, 3(1), 115-130.

Mangkunegara, A.P. (2011). Perencanaan dan pengembangan sumber daya manusia. Bandung: Rifeka Aditama.

Mukolwe, J. O., Michael, O., Ajowi, O., \& Jack. (2017). Implementation of total quality management in primary schools as a panacea for low academic achievement. European Journal of Research in Social Sciences, 5(5), 54-63. 
Implementation and Impact of Human Resources Development in Improving the Performance of Teachers in Schools (Multi Case Studies)

Nadarajah, S. (2012). The relationship of $\mathrm{hr}$ practices and job performance of academicians towards career development in malaysian private higher institutions. Procedia - Social and Behavioral Sciences, 57, 102-118.

Omebe, C. A. (2014). Human resource management in education: Isues and challenges. British Journal of Education, 2(7), 26-31

Saw., \& Watana. (2020). The relationship between teachers' perceptions towards human resource management and school climate at myint-mo education foundation (mef) in myanmar. Scholar: Human Sciences, 12(1), 219-229.

Septi, I. A. Y, (2012). Strategi peningkatan mutu manajemen melalui pengembangan program sekolah. Jurnal Manajemen Pendidikan, 23(5), 424-433.

Suhardan, D. (2014). Supervisi profesional layanan dalam meningkatkan mutu pembelajaran di era otonomi daerah. Bandung: Alfabeta.

Suharto, (2017). The effect supervision, school culture, and work commitment of job performance Primary School in principal of administrative region Ii City West Jakarta, Journal of Education Research in Administration and Management, 1(3), 1.

Talan, A., \& Tyagi, R. D. (2020). Sustainability: Fundamentals and applications. Wiley Online Library.

Tam, T. P., S. Catherine. C., \& Jill, Z. (2018). A systematic literature review of faculty development for teacher educators, Higher Education Research \& Development, 37(2), 373-389.

Vosloban, V. I. (2012). The Influence of the Employee's Performance on the company's growth - a managerial perspective. Procedia Economics and Finance, 3, 660 - 665.

Widodo, A., Riyanto, Y., \& Roesminingsih, R. (2020). Implementation of islamic Senior Hight School academic quality assurance (Multi-site study at Islamic Senior High School of Surabaya and Islamic Senior High School of 2 Malang). International Journal of Recent Educational Research, 1(3), 233-245.

Wijaya, E. Y., Sudjimat, D. A., \& Nyoto, A. (2016). Transformasi pendidikan abad 21 sebagai tuntutan pengembangan sumber daya manusia di era global. Prosiding Seminar Nasional Pendidikan Matematika, 1, 263-278.

Zein, M. S. (2016), profesional development needs of primary efl teachers: perspectives of teachers and teacher educators. Journal Professional Development in Education, 43 (2), 293-313

Zuhro, A. (2015). Total quality management: Capaian kualitas output melalui sistem kontrol mutu sekolah. Cendekia, 9(1), 79-94.

${ }^{*}$ Dr. Muh Burhanudin Harahap (Corresponding Author)

Universitas Negeri Surabaya, Indonesia

Jl. Raya Kampus Unesa, Lidah Wetan, Kec. Lakarsantri, Surabaya, Indonesia

Email: muh.harahap16070976008@mhs.unesa.ac.id

Prof. Dr. Maria Veronika Roesminingsih

Universitas Negeri Surabaya, Indonesia

Jl. Raya Kampus Unesa, Lidah Wetan, Kec. Lakarsantri, Surabaya, Indonesia

Email: roesminingsih@unesa.ac.id 
Implementation and Impact of Human Resources Development in Improving the Performance of Teachers in Schools (Multi Case Studies)

\section{Dr. Mudjito}

Universitas Negeri Surabaya, Indonesia

Jl. Raya Kampus Unesa, Lidah Wetan, Kec. Lakarsantri, Surabaya, Indonesia

Email: mudjito@unesa.ac.id 